\title{
Relationship between Teachers and Students Objective Needs
}

\author{
*Udoh Victoria Chinwe \\ General Studies Unit, Tansian University, Umunya, Anambra State, Nigeria.
}

\begin{abstract}
Learning objectives are statements that describe what a learner will be able to do as a result of learning. They are sort of contract that teachers go into with students. Objectives explain elaborately what students will be able to do after learning. The objective needs of both teachers' and students are like Siamese twins. None can exist without the other. The main thrust of this paper therefore is to explore the relationship between teachers' objective needs and students' objective needs. Also how the teachers should help the students to achieve their objectives.
\end{abstract}

\section{RELATIONSHIP BETWEEN TEACHERS' OBJECTIVES NEEDS AND STUDENTS' OBJECTIVE NEEDS.}

Objective needs of teachers and students can only be discussed with reference to an academic environment. Academic environment is related to education. Education is the greatest hope of any developing country. Teachers are facilitators of education. A teacher can be defined as a person who has the basic qualifications required for the transmission of knowledge, skill and information. A teacher is a person assigned the role of transmitting to the present generation the accumulation knowledge and values of the past and these interprets this information with reference to the present with a view to modifying and improving the future. A teacher is a person who provides education for students.

In the past, many people thought that anyone who could hold pieces of chalk and stand in front of the learners is a teacher. Studies have shown this to be wrong. For any nation to do well in the education sector, such a nation must employ qualified teachers who can facilitate learning so as to achieve the set out objectives.

\section{WHAT ARE THESE OBJECTIVES WHICH TEACHERS ARE TO ACHIEVE}

Ogedimuo (2009) defines objective as a required outcome that a person or organization expects to achieve within a specified time. Also Onyemerekeya (2003) defines educational objectives as statements which describe in a relatively specific matter what a student should be able to do or produce or what the characteristics are that the students should posses after completing educational programme.

Bloom et al (1981) referred to objectives as domains of learning and according to him, there are three categories of these objectives and they are cognitive, objectives, affective objective and psychomotor objectives. These objectives relate to areas of expected outcomes after teaching or instructions are carried out by teachers.

Objectives are tools that underlie all planning and strategic activities. These serve as a stepping stone for teaching and for assessing students performances.

Still on this, the National Policy on Education (2004) also contains the government national objectives with regards to Nigerians Educational system. These objectives are as follows:

1. A free and democratic society.

2. A just and egalitarian society.

3. A united, strong and self reliant nation.

4. A great and dynamic economic.

5. A land bright and full of opportunities for citizen.

The above mentioned points are educational objectives, meant for the entire school system to achieve. These are outcomes of education expected after citizen of this country must have gone through the country's educational system. Now the question is; can these objectives be actualized? Yes, but this can only be possible through teachers employed in the school system to facilitate education. For these objectives to be actualized, teachers should set out their own objectives so as to be able to actualize the national objectives of education.

\section{TEACHERS OBJECTIVE NEEDS}

As earlier explained teachers are facilitator of education and at that they must have some objectives which they set to achieve. The objectives of teachers are the expected outcome of teaching. They are those things a teacher expects a student to know after teaching session. Objective needs of teachers are students centered. It is the duty of a teacher to map outcomes to be achieved. 
Teachers objective needs are those strategies through which the mapped out objectives can be achieved. These strategies have to be implemented, putting into consideration also the national objectives. Teachers' objectives serves as a guide for teaching. The objectives dictates to teachers what to emphasize in the process of teaching, it gives them focus. It is worthy to note that without objective needs, teachers cannot really relate their teaching to real life or carry the student along and when this is the case the aim of teaching will almost be useless.

\section{TEACHERS' OBJECTIVE NEEDS/STUDENTS OBJECTIVE NEEDS}

Teachers' objectives need rests on the fact that these objectives are meant for students. Teachers objectives are students centered. A student is a learner or someone who attends an educational institution. Davis (1997) states that in some nations the term student is reserved for those who attends university. In general, a student is used for anyone who is learning.

In the Nigerian educational system, students with reference to undergraduates, that is those that have not been awarded any degree have their objectives of being there. These objectives include:

- $\quad$ Getting good qualification at the end of study.

- $\quad$ Attaining self reliance after years of study.

- $\quad$ Acquisition of right attitudes, values, which will help for the survival of the students and the Nigeria society at large.

Considering these objectives needs of students, it is pertinent to note that these objective needs can only be attained in school and as a result of this, teachers tailor their objective needs in line to the needs of students. Teachers objectives needs are student centered and when teacher put this into consideration, their own objectives needs are actualized.

\section{RELATIONSHIP OF TEACHERS' OBJECTIVES AND STUDENTS' OBJECTIVES}

The major relationship between these two objectives is that the two cannot be separated from one another. The teachers' need the students to carry out these objective and at the same time, students can only actualize their own objectives with the help of the teachers.

For the objective needs of teachers' to be actualized, they must be sincere with their profession. The primary aim of a good teacher is to help students achieve learning objectives through encouragement, being resourceful and at the same time through diligent. For teachers' to achieve these objectives they must put into consideration the individual differences of their students. Students learn more easily when they are at peace with their teachers. It is also of great importance for teachers to show genuine concern for students general academic well being.

Teachers should establish an environment for respect and good interaction with students. From this interaction, teachers' can get feedbacks from students and through these, teachers can determine to what extent they are attaining their objectives. To this end, the teachers' objectives and students' objectives can be attained if both parties concerned should be accommodating, diligent, hardworking and sincere. The government is also an important factor through which these objectives can be attained. The government should improve the conditions of service for teachers, giving them motivation, ensuring that educational activities are carried out at conducive environments and that qualified teachers are employed in the Nigerian school system.

Conclusively, the relationship between teachers objectives and students objectives lies in the fact that it is through the teachers activities that the students' objectives needs are to be attained.

\section{References:}

[1] Bloom et al (1981) Taxonomy of Educational Objectives: Hand book II: Affective Domain. New York: Mckay Press, Inc.

[2] Davis, J. (1997) Better Teaching, More Learning. Phoenix: American Council on Education. New York: Oryx Press.

[3] Federal Republic of Nigeria (2004) The National Policy on Education. Lagos: Federal Ministry of Information.

[4] Hornby, A.S (ED) (2000) Oxford Advanced Learner's Dictionary of current English (5 ${ }^{\text {th }}$ Ed). Oxford: Oxford University Pres.

[5] Ogedimuo, J. (2009) Teaching and Learning Objectives. Ibadan: Wasons Publishers .

[6] Onyemerekeya, C. (2003) Curriculum implementation. Owerri: Versatile Publishers. 